\title{
The neurological junction between the appendix and ascending colon
}

\author{
JOHN L. EMERY AND JANET UNDERWOOD \\ From the Congenital Anomalies Research Centre, University of Sheffield
}

SUMMARY The junction between gut wall having the intramural plexus distribution characteristic of large bowel and that of appendix does not occur at the anatomical junction of the caecum and the appendix but at a level proximal to this and just distal to the ileocaecal valve.

The intramural ganglionic plexus of the appendix differs from that of the rest of the intestine in that instead of the nerve cells being clearly stratified into distinct plexuses, they are arranged in an apparently irregular pattern within the muscle layers.

While studying the intramural plexus of the colon of immature infants who had delayed bowel activity and seeking the site of origin of the appendix in the conical caecum seen in such infants (Fig. 1), we were surprised to find that the whole of the muscle of the immature conical caecum and appendix appears to have the same ganglionic plexus distribution as the adult appendix. It soon became obvious that in elder children the gross anatomical junction of the appendix with the colon does not coincide with the neurological one.

This paper reports an attempt to define the apparent caeco-appendicular neuronal junction.

\section{Method}

The appendix and caecum from 74 children varying in age from stillborn at $\mathbf{3 8}$ weeks gestation to children of 12 years, were examined. Eighteen were obtained from operation specimens and the rest were at necropsy.

The specimen of colon, caecum and appendix

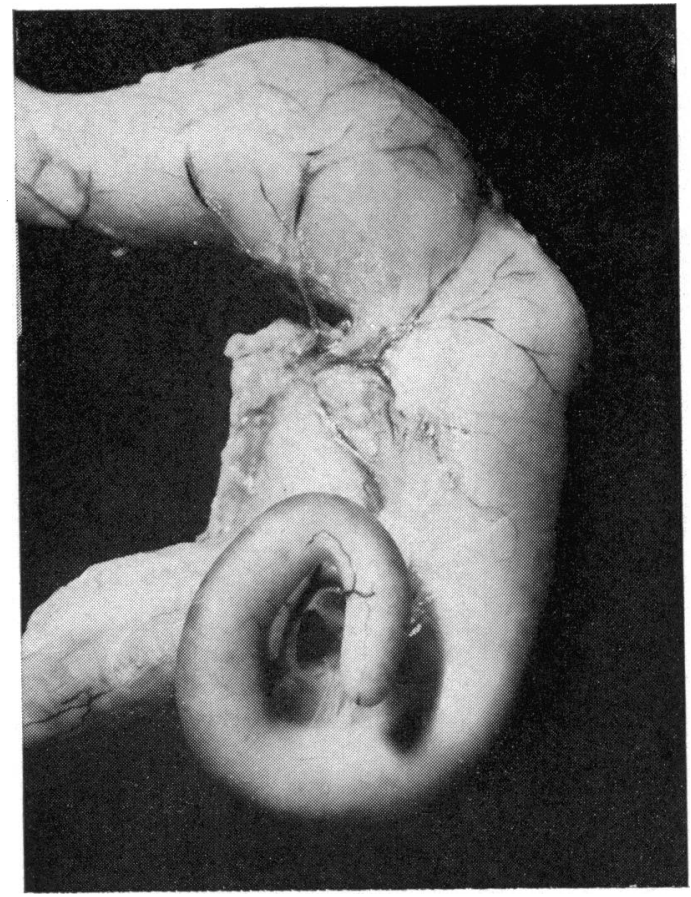

FIG. 1 Photograph of the ascending colon, ileocaecal region and appendix from a newborn child of 36 weeks maturity, showing the conical formation of the caecum and appendix and also the absence of obvious longitudinal striae on the surface of the colon. 


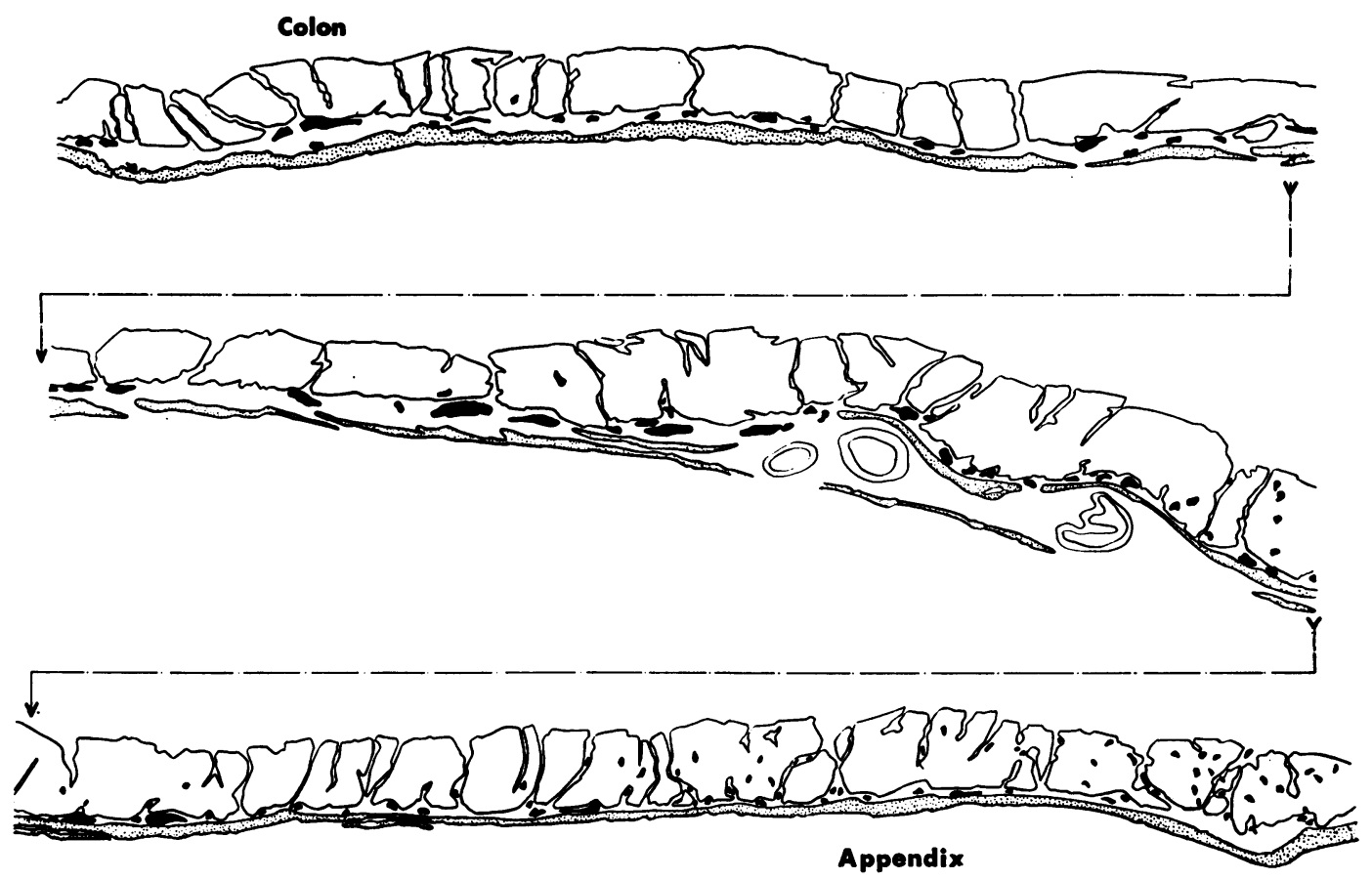

FIG. 2 Drawing from a projection microscope study of a strip section taken from the wall of the colon to the appendix. The intramural ganglionic plexus is shown as solid black, the circular muscle bundles clear and the longitudinal muscle stippled. Note the difference between the distribution of ganglionic tissue in the colon at the top of the drawing and the appendix at the lower part. The junction between the colon and the appendix occurs approximately at the junction between the mid and lower tracings.

was opened down the side opposite to the ileocaecal valve and pinned out flat. Mapped strips of bowel could then be cut longitudinally from the appendix to both the ileum and caecum. The strips were snap frozen and $10-20 \mu$ sections cut at $-25^{\circ} \mathrm{C}$ in a cryostat. These were stained with Solochrome Cyanin (Hyman and Poulding, 1961).

\section{Results}

The general distribution of ganglia in the colon and appendix as seen in our strips is illustrated in Figure 2. In this figure the junction between the appendix and colon would be indicated by the junction between the mid and lower range of the tracing where at least as much ganglionic plexus resides outside the intermuscular layers as between them (Figure 3).

In none of the specimens studied did the change in ganglion distribution coincide with the anatomical junction between the appendix and caecum. The junction lay at an irregular line around the caecum just below the ileocaecal junction and running slightly obliquely from this as illustrated in Figure 4. In no case did we see appendix-like innervation extending into the ileum but in several cases, it appeared to approach the appendicular border of the ileocaecal valve.

\section{Discussion}

Most studies of the appendix are confined to the vermiform structure. There have been many 

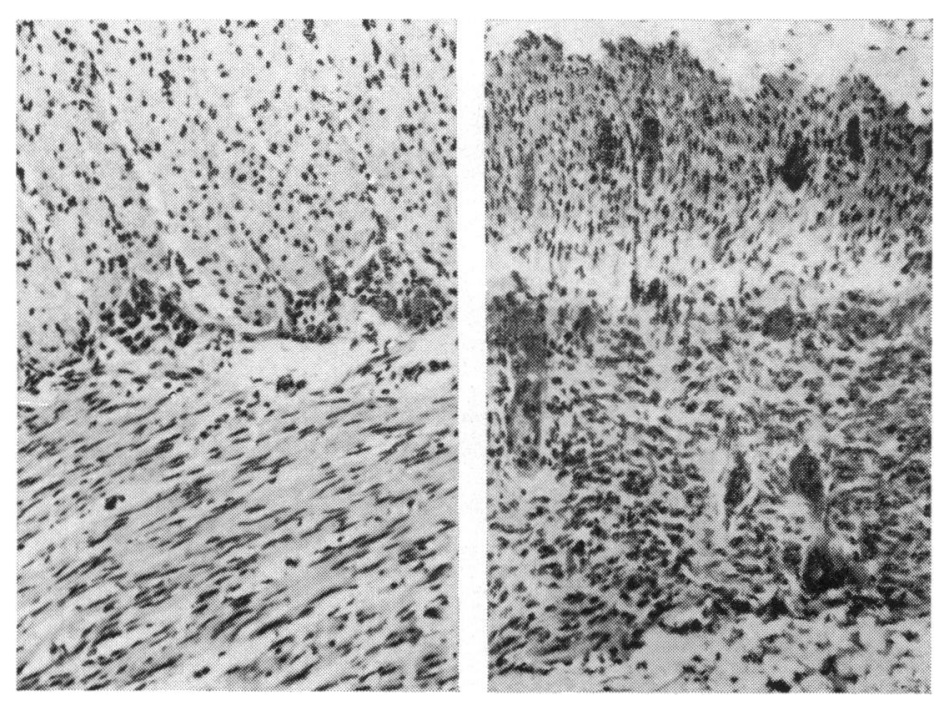

FIG. 3 Photomicrograph of the muscle of the colon (left), and of the muscle of the appendix (right). Frozen sections from the same child stained with solochrone cyanin to show the different distribution of ganglionic tissue in the two structures.

studies of the intrinsic nervous tissue (Reiser, 1932; Sato, 1935; Makii, 1937; Lassman, 1952; Shersheneva, 1959; Yamamoto, 1960; Erdohazi and Read, 1967) and a number of studies have been carried out on changes in the nerves of the appendix associated with both acute and chronic appendicitis (Reiser, 1932; Walcker, 1932; Drüner, 1936; Schuringa, 1940; Llombart and Alcober, 1953; Röper, 1952; Simard, 1935).

Our findings suggest that from a nerve functional point of view, the caecum below the level of the ileocaecal valve should be considered the same as that of the vermiform appendix. This is borne out by some radiological studies (Pressler, 1962 , suggesting that the appendix and caecum do function as one. An observation of Gross (1927) is also relevant. He noticed that electrical stimulation of the appendix does not cause contraction of the large bowel but of the ileocaecal valve.

Photographs by Mr A. Tunstill. Janet Underwood is working under a grant from 'Action for the Crippled Child'.

\section{References}

Conti, G. (1952). Uber die Veränderungen der sympathischen Ganglienzellen des Appendix vermiformis in Abhängigkeit vom Lebensalter und im Verlauf der chronischen Appendicitis. Schweiz. Z. allg. Path., 15, 80.

Drüner, L. (1936). Uber die rezidivierende Appendizitis. Bruns' Beitr. klin. Chir., 164, 394-395.

Erdohazi, M., and Read, C. R. (1967). A histological study of the appendix vermiformis. Develop. Med. Child Neurol., 9, 98-101.

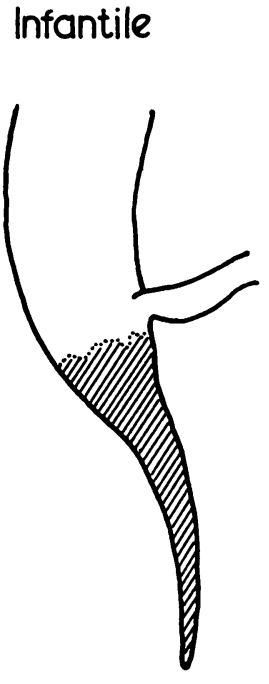

Mature

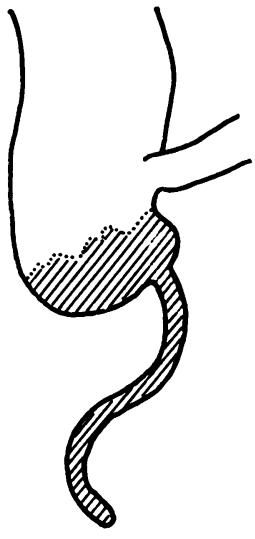

FIG. 4 Diagrammatic representation of the distribution of the diffuse, appendix-type intramural ganglionic plexus in the infantile and mature caecum and appendix. The shaded area represents the area where appendix-type structure is found.

Gross, W. (1927). Physiologische Zusammenhänge der Appendix mit der Bauhinschen Klappe (bei Operationen nachgewiesen). Münch. med. Wschr., 74, 1130-1131.

Hyman, J. M., and Poulding, R. H. (1961). Solochrome cyanin iron alum for rapid staining of frozen sections. J. Med. Lab. Technol., 18, 107.

Lassmann, G. (1952). Terminale nervöse Struktur in der neurogen Appendicopathie. Acta neuroveg. (Wien), 4, 25-30.

Llombart, A. and Alcober, V. (1953). Uber eine besondere Form $C$ der sympathischen Hyperplasie bei der chronischen, obstruktiven Appendicitis. Beitr. path. Anat., 113, 90-99.

Makii, T. (1937). Histologische Untersuchung über die Veränderungen der Nervenapparate des Wurmfortsatzes und des Mesenteriolums bei Appendizitis. Jap. J. med. Sci., IX, $5,1-15$.

Pressler, K. (1962). Die Füllung der gesunden Appendix. $ᄋ$ Radiologe, 2, 177-184.

Reiser, K. A. (1932). Der Nervenapparat im Processus $D$ vermiformis nebst einigen Bemerkungen über seine Veränderungen bei chronischer Appendicitis. Z. Zellforsch., $15,761-800$.

Röper, K. (1952). Klinische und neurohistologische Studien über den Verlauf der Appendicopathia neuromatosa. N Acta neuroveg. (Wien), 4, 9-22.

Sato, Y. (1935) Uber die Verteilung der nervösen Elemente in $\omega$ dem Wurmfortsatz des Menschen. Mitt. allg. Path. (Sendai), 8, 283-298.

Schuringa, A. A. (1940). Over het voorkomen van appendicitis, in het bijzonder van de z.g. neurogene appendicitis in Nederlandsch-Indië. Geneesk. T. Ned.-Ind., 80, 1391-1401. ?

Shersheneva, E. N. (1959). The development of the appendix $\square$ vermiformis and of its innervation. Dokl. Akad. Nauk. $S S S R, 125,424$.

Simard, L. C. (1935). On the frequency of nervous lesions of the vermiform appendix: neuro-appendicopathy. Canad. med. Ass. J., 33, 518-521.

Walcker, F. I. (1932). Die Bedeutung der Bauhinischen und $O$ appendikulären Klappe. Experimentelle und anatomische Untersuchungen. Arch. klin. Chir., 170, 706-721.

Yamamoto, T. (1960). Electron microscope investigation on the relationship between the smooth muscle cell of the proc. vermiformis and the autonomic peripheral nerves. Acta Neuroveg., 21, 406-425. 